\title{
Relationship between emotional problems, demographic variables and experience of psychological symptoms in Kurdistan University students in 2018
}

\author{
Hazhir Mahmodi Panah', Ayat Jafari ${ }^{1}$, Fateh Sohrabi ${ }^{2}$ \\ 1.M.Sc of Clinical Psychology, Department of Psychology, Kurdistan University, Sanandaj, Iran . \\ 2. PhD Student of Clinical Psychology, Department of Clinical Psychology, Shahid Beheshti University, Tehran, \\ Iran (Corresponding Author). $\quad$ E-mail: F.sohrabi20@g mail.com
}

Received: 01/07/2020

Accepted: 11/10/2020

\begin{abstract}
Introduction: Emotional relationship with opposite sex is an important matter during university ages and affects students' function.

Aim: This study aimed at surveying the relationship between demographic variables of students with emotional problems and their attitude toward it.

Method: As a descriptive-survey study, among Kurdistan university students, through in-access sampling method, those who signed informed consent were selected as the sample of study. The asked-questions were about the experience of emotional relationship, failure and their attitude toward them. Using SPSS version 20, the raw data were analyzed by Ki-square and Spearman correlation coefficient tests.
\end{abstract}

Results: Finally 405 students (171 girls, 232 boys, 2 missed) with the mean age of 22 years old and 3.49 SD, completed the necessary data and questions. Results showed that emotional relationship is a popular experience among students. Beside its consequences, it is not necessarily negative. And along with problems it may be caused, the students have an acceptable attitude toward it. Also, there were not any gender differences in the severity of experienced symptoms after a failure experience, and the failure rate in these relationship decreased by the age.

Conclusion: Emotional relationship can make some bad experiences for students temporarily, but it seems that we have to note the other side, which seems to development stage that inevitably has its positive and negative sides.

KeyWords: Emotional relationship, Psychiatric symptoms, Demographic variables, Student

\footnotetext{
How to cite this article : Mahmodi Panah H, Jafari A, Sohrabi F. Relationship between emotional relationship, demographic variables and experience of psychological symptoms in Kurdistan University students in 2018, a qualitative study. Shenakht Journal of Psychology and Psychiatry. 2020; 7 (5): 30-40.URL: http://shenakht.muk.ac.ir/article-1-868-en.pdf
}

Copyright (C) 2018 the Author (s). Published by Kurdistan University of Medical Sciences. This is an open access article distributed under the terms of the Creative Commons Attribution-Non Commercial License 4.0 (CCBY-NC), where it is permissible to download, share, remix, transform, and buildup the work provided it is properly cited. The work cannot be used commercially without permission from the journal. 


\title{
ارتباط بين مشكلات عاطفى، متغير هاى جمعيت شناختى و تجربه علأمم روانيزشكى در دانشجويان

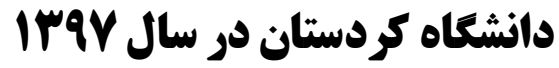

\author{
هزير محمودى بناه'، آيت جعفرى'، فاتح سهر ابى' \\ ا..كارشناسى ارشد روانشناسى بالينى، گروه روانشناسى، دانشكاه كردستان، سندج، ايران.

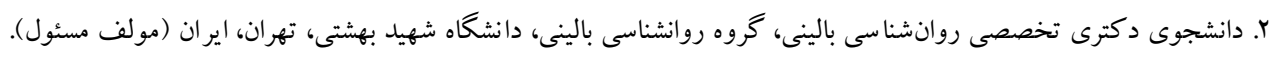

ايميل:F.sohrabi20@gmail.com

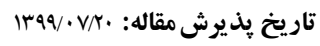

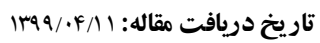

جكيده

مقدمه: رابطه عاطفى با جنس مخالف موضوع مهمى در دوران دانشگاه است و اثرات متعدد و متفاوتى بر عملكرد دانشجويان دارد. هدف: هدف اين مطالعه بررسى رابطة بين متغيرهاى جمعيت شناختى با مشكلات عاطفى و ديد گاه دانشجويان نسبت به آن بود.

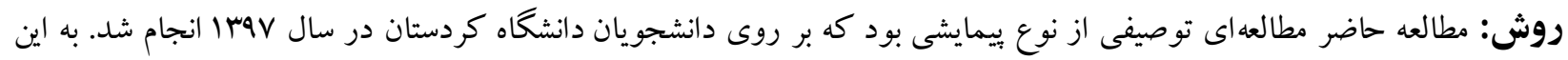
منظور از طريق نمونه كيرى در دسترس دانشجويانى كه با رضايت شخصى اطلاعات مورد نياز را تكميل نمودند، به عنو ان نمونه انتخاب شدند. ابزارهاى يزٔوهش شامل مجموعهاى يرسش هاى مربوط به تجربهُ روابط عاطفى بو د. دادههاى به دست آمده از طريق نسخهُ بيستم SPSS

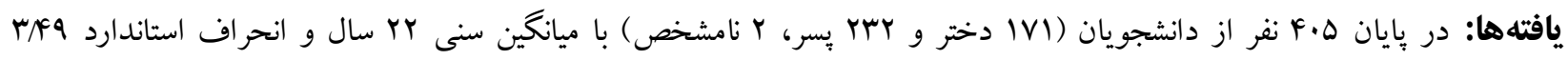

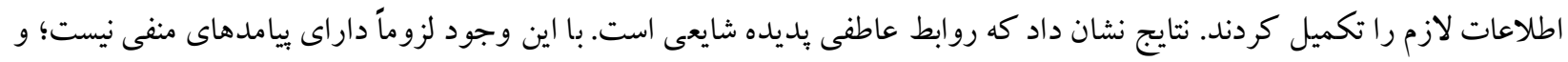

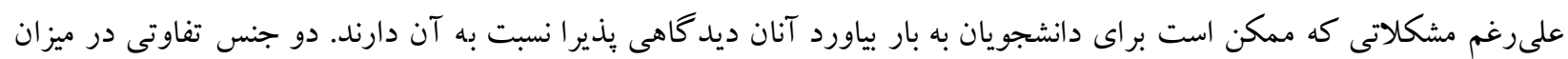
مشكلات متعاقب گسست عاطفى تجربه نمى كنند و با افز ايش سن از ميزان اين تجربيات كاسته مىشود.

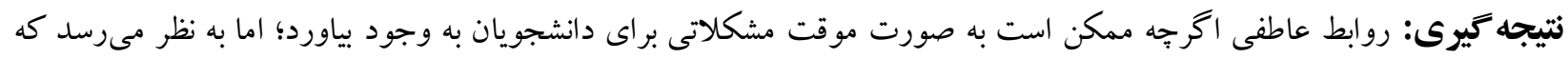

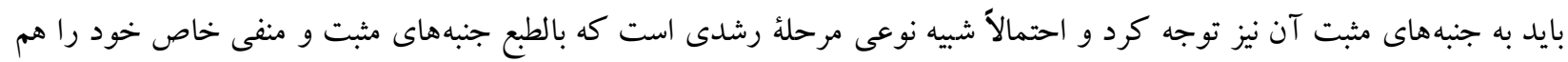
زمان با هم داراست.

كليدوازهها: روابط عاطفى، علائم روانيزشكى، متغيرهاى جمعيت شناختى، دانشجويان 
مرضى اختلال روانى كه پِ از اين روابط پيديدار مى مقدمه

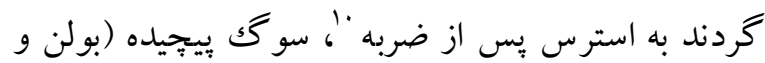

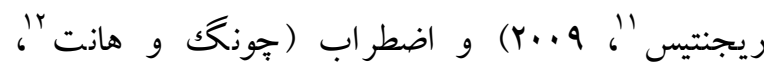

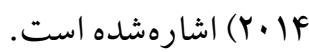
اما هميشه اين گونه نيست، درواقع همهى افراد در پِاسخ به رويدادهاى ناكو ار مانند شكست رابطهى عاطفى دهيار

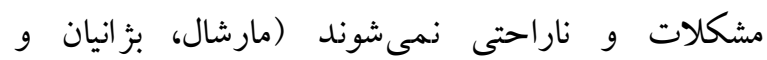

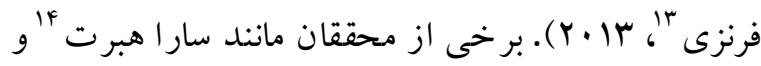

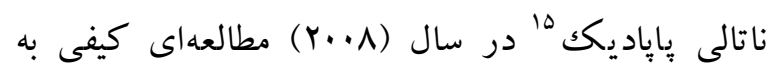
منظور كاوش عميق در تجارب افراد پِ از پايان رابطه انجام دادند. نتايج آنان نشان داد كه اكثر افراد علاوه بر تجارب ناكوار، تجارب مثبت و سازندهاى را بـس از يايان رابطه عاطفى تجربه كرده بودند و زمانى كه در مورد مهمترين تغيير سؤال مى شد آنان به تغييرات مثبت اشاره مى كردند. همجينين در بعضى از بزّوهشهاى داخلى ارتباط معنادارى بين شكست عاطفى با تجربهُ اضطر اب

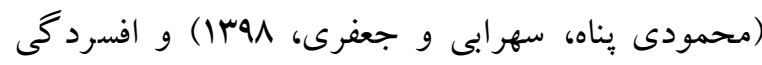
يافت نشده است (يوسفى، جعفرى، محمودى پيناه و سهرابى، 19 1). همان گونه كه اشاره شد در مورد يايان رابطه عاطفى و تأثيرات آن در مطالعات موجود توافق يكدستى وجود ندارد و نيازمند تحقيقات بيشترى در اين زمينه است.

البته برخى محققين شدت ناراحتى و مشكلات يس از يايان رابطه را با عواملى گوناگونى مرتبط ميىدانند

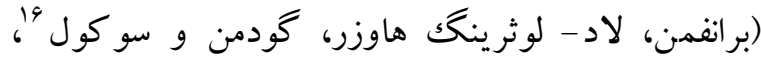

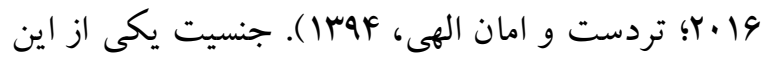

${ }^{10}$ - Post-Traumatic Stress Disorder (PT SD)

11 - Boelen \& Reijntjes

${ }^{12}$ - Chung \& Hunt

13 - Marshall, Bejanyan \& Ferenczi

14- Sarah Hebert

15 - Natalee Popadiuk

${ }^{16}$ - Bronfman, Ladd-Luthringshauser, Goodman \& Sockol

3 - Cameron, Palm \& Follette

4 - East wick, Finkel, Krishnamurti \& Loewenstein

5 - Boals

6. Perilloux \& Buss

7- Rhoades, Kamp Dush, Atkins, Stanley \& Markman

8 - Field, Diego, Pelaez, Deeds \& Delgado

${ }^{9}$ - Waller \& MacDonald 
با دانشگاه است، احتمال وقوع آن بيشتر نيز مى گردد. بسيارى از تحقيقات به مطالعات عواقب و مسائل روانشناختى متعددى كه به دنبال آن به وجود مي آيد،

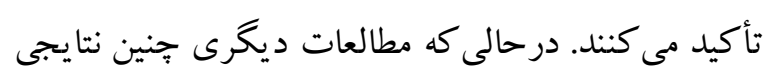

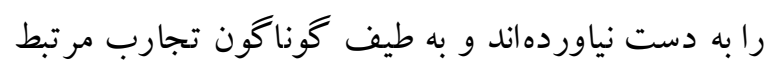
با آن اشاره مى كنند؛ بنابراين از آنجايى كه تجارب و و

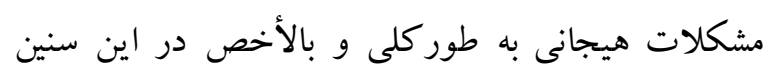
دغدغه مهمى براى متخصصان حوزهى سلامت روان

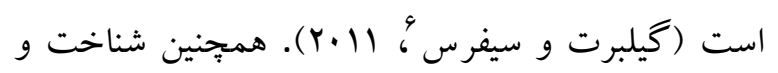

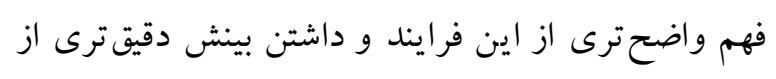
آن همراه با در كك عوامل كوناكون مرتبط با اين بديده

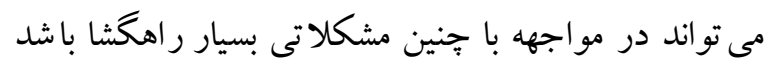

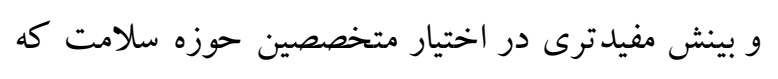
در د انشكاه ها مشغول به فعاليت هستند، قرار دهد. از اين رو بثزوهش حاضر بر آن است كه ارتباط مشكلات

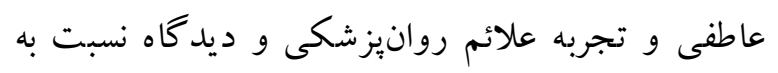
اين مسائل و همجنين ارتباط آن با مؤلفه هاى جمعيت

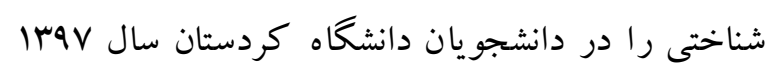
بررسى كند.

\section{روش}

اين مطالعه از نوع مطالعه كيفى است كه در آن

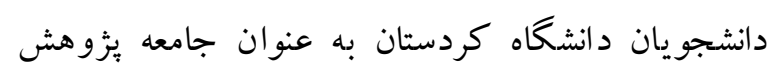
بودند، در سال Ir I انجام شد. به اين منظور از طريق نمونه گيرى در دسترس، دانشجويانى كه با رضايت شخصى يرسشنامه ها و سؤال هاى كيفى مربوط به يثزوهش را باسخ دادند به عنوان نمونه انتخاب شدند. اين فرايند نمونه گيرى در بازه زمانى سه ماهه (دى ماه لوسا تا اسفند

\section{${ }^{6}$ - Gilbert \& Sifers}

عوامل است كه با شدت ناراحتى يس از بايان رابطه

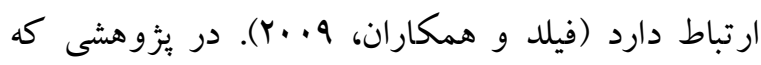

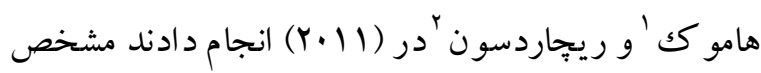
مشخص شد كه مردان يُ إز رابطه بيشتر ناراحت و و

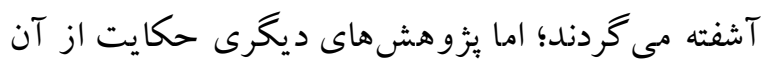
دارند كه زنان نسبت به مردان به دنبال شكست ر ابطه بيشتر ناراحت مى شدند و همجينين از افسردگى شديدترى رنج مىبرند؛ اما مردان با احتمال بيشتر يّ از طرد إد از رابطه اقدام به خود كشى كنند (وارب، جنكينز، كالاهان و و

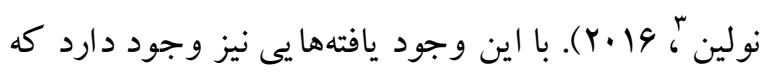
به تفاوت معنادارى بين مردان و زنان دست بيدا نكر دهاند

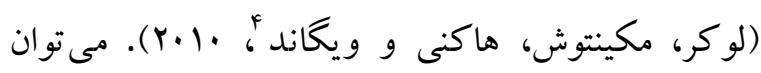
كفت كه نقش جنسيت در ناراحتى بِس از رابطه نتايج مغايرى وجود دارد كه نيازمند تحقيقات بيشترى است

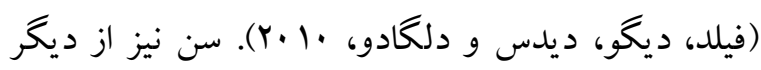
عوامل مؤثر در تجربهى ناراحتى پِّ از رابطه است جراكه شكست رابطه عاطفى در اوايل جوانى تأثير

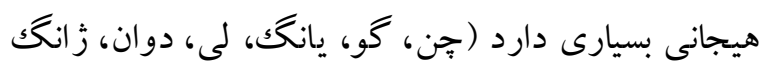
و زى معنادارى بين ناراحتى پِ از پايان ر ابطه عاطفى با سن را

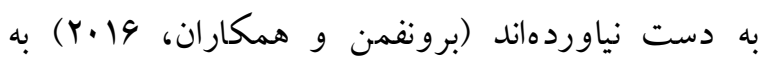
طوركلى سن ازجمله عواملى است كه كمتر مورد يثزوهش قرارگرفته است و روشن ساختن نقش آن نيازمند تحقيقات بيشترى در اين زمينه است (واربٍ و همكاران،

بنابراين، مىتوان گفت كه رابطه عاطفى بديدهاى شايع است و در سنين نوجوانى و جوانى، سال هاى كه مصادف

\footnotetext{
1. Hammock

2- Richardson

3 - Wrape, Jenkins, Callahan \& Nowlin

${ }_{5}^{4}$ - Locker, McIntosh, Hackney, Wilson \& Wiegand

5 - Chen, Guo, Yang, Li, Duan, Zhang \& Ge
} 


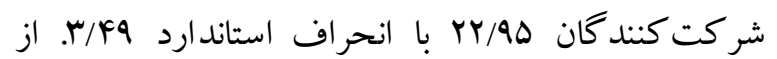
ميان شركت كنند كان (ه/ه/\%) متأهل بودند با نفر نيز به اين سؤال باسخ نداده بودند. از لحاظ مقطع تحصيلى roV نفر (MT/\%) در مقطع

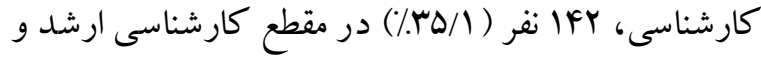

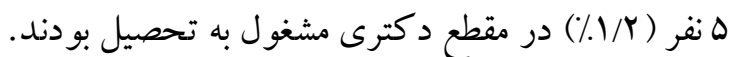
به طور كلى بهو نفر ( •9 درصد) از دانشجويان بيان كردهاند كه رابطه عاطفى داشتهاند و 119 درصد) رابطه عاطفى نداشته و نزديكك به 4\& نفر نيز به اين

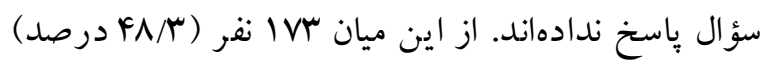
نفر بيان كردهاند كه شكست عاطفى را تجربه كردهاند.

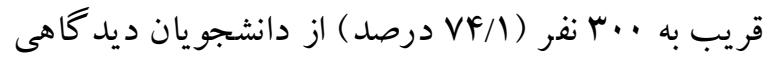

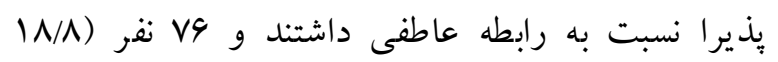
درصد) آن را تجربهاى منفى و غير قابل قبول دانستند و سايرين نيز QY نفر (V/Y درصد) نظرى نداشتند. در كل

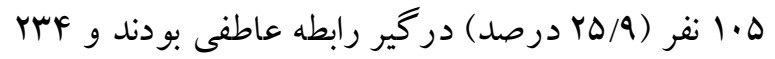
نفر (هV درصد) در كذشته آن را تجربه كردهاند و حدود F نف (19 درصد) تجربه آن را كزارش نكردند. در مورد تجربه علائم روانى عه نفر (س/سr\%) اعلام كردند كه هيج مشكل خاصى را تجربه نكرده اند؛ اما سايرين كه . مشكلات خانوادكى، مشكلات تحصيلى، مشكلات هيجانى گز ارش دادند. به منظور بررسى رابطه جنسيت و مقطع تحصيلى با ديد كاه نسبت به آن، تجربه روابط عاطفى، تجربه شكست و همينطور مشكلات بعد از آن

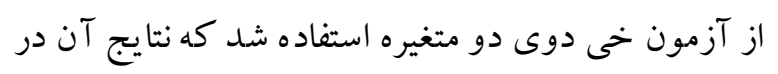
جدول شماره آمده است.

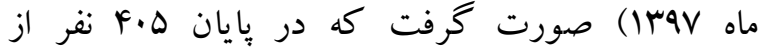
دانشجويان يرسش هاى كيفى مورد نظر ياسخ دادند. به منظور رعايت اخلاق يثوهش هيج گونه اطلاعات هويتى شركت كنندكان در برسشنامهها درج نشده و از روش

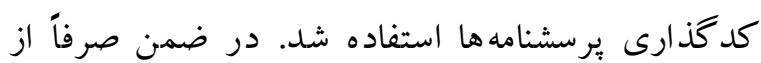
كسانى كه رضايت كامل داشتند اطلاعات مربوطه اخذ كرديد. در بايان نتايج حاصله از طريق نسخه ·ب نرمافزار آمارى SPSS با روش هاى آمارى توصيفى و استنباطى (همبستخى اسييرمن و خى دو) مورد تجزيه و تحليل قرار كرفت. در اين ئزوهش از ابراز ساختار يافتهاى استفاده نشد بلكه متناسب با هدف ئزوهش از سؤ ال هاى خاصى در ارتباط با تجارب مربوطه استفاده شد. سؤ الهاى كيفى مورد نظر شامل سؤالهايى بود كه به ترتيب راجع به داشتن رابطه عاطفى، ديدكاه نسبت به آن، تجربه شكست در رابطه عاطفى با جنس مخالف و ميزان تحت تأثير آن قرار كرفتن و همجنين حالات تجربه شده ناشى از آن بودند كه همراه با آنها علاوه بر اطلاعات جمعيت شناختى مانند سن، جنس، مقطع تحصيلى، رشته تحصيلى، وضعيت تأهل، نيز از آنان اخذ كرديد.

\section{يافته ها} در يايان ه.F نفر از دانشجويان به اطلاعات مو جود در

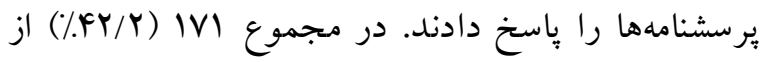

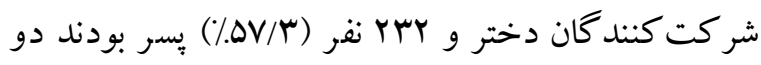
نفر نيز به اين سؤال ياسخ نداده بودند. ميانخين سنى كل 
جدول ا نتايج آزمون خى دو متغيره براى بر رسى رابطه جنسيت و مقطع تحصيلى با روابط عاطفى،

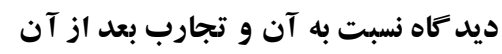

\begin{tabular}{|c|c|c|c|c|c|c|c|c|c|}
\hline \multirow[b]{2}{*}{ معنادارى } & \multirow[b]{2}{*}{ כرجه } & \multirow[b]{2}{*}{ ارزش } & \multicolumn{2}{|c|}{ كل } & \multicolumn{2}{|c|}{ از دست رفته } & \multicolumn{2}{|c|}{ معتبر } & \\
\hline & & & درصد & فراوانى & درصد & فراوانى & درصد & فراوانى & \\
\hline.$/ 190$ & 1 & Y/TDV & $1 \ldots$ & $r \cdot \Delta$ & $11 / 9$ & FA & $M / 1$ & $M V \Delta$ & 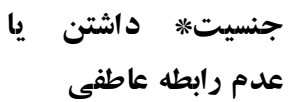 \\
\hline $.1 .4 q$ & 1 & $F /|V|$ & $1 \ldots$ & $f \cdot \Delta$ & $V / f$ & $\mu$. & $9 r / 9$ & MV & نسبت بله رابطه عاطفى \\
\hline$\cdot / 1 \cdot \Delta$ & 1 & $r / \Lambda \cdot r$ & $1 \ldots$ & $f \cdot \Delta$ & $19 / 1$ & 91 & $\Lambda \Gamma / r$ & rrv & تجربيت مشكلات تجربه يا عد م \\
\hline $.1 .9 \mathrm{~V}$ & $r$ &.$/ \mathrm{Fr}$ & $1 \ldots$ & $f \cdot \Delta$ & $\mid r / A$ & $\Delta r$ & $\Lambda V / r$ & ror & 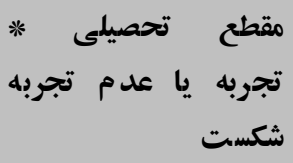 \\
\hline$\cdot|| F \mid$ & $r$ & . /TrV & $1 \ldots$ & $f \cdot \Delta$ & $\mathrm{IV} / \mathrm{\Delta}$ & vi & $\Lambda r / \Delta$ & Mr & مقطربه \\
\hline .1994 & $r$ & .1 .94 & $1 \ldots$ & $F \cdot \Delta$ & $\Lambda / 1$ & r & $91 / 9$ & MV & 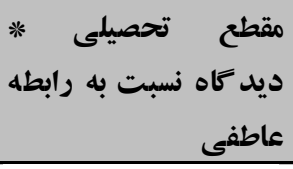 \\
\hline
\end{tabular}

مشكل خاصى را تجربه نكردهاند. نتايج نشان داد كه رابطه معنادارى بين دو متغير وجود ندارد (ه (1/ (p=). به اين معنا دو جنس در تجربه مشكلات متعاقب روابط عاطفى مس بـى تفاوتى نشان ندادند. در مورد ارتباط بين جنسيت و

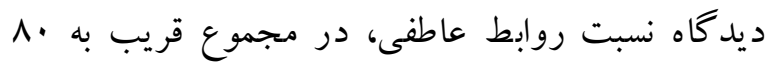
درصد ( (هF درصد بهر ان و نزديكك به ها در صد دختران)

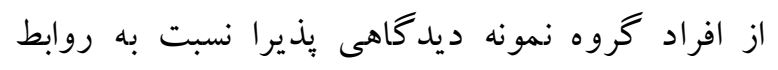

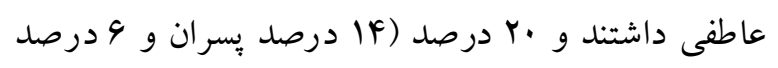
دختران) ديگر آن را تجربهاى قابل قبول نمىدانستند. نتايج حاكى از ارتباط معنىدار بين دو متغير بود

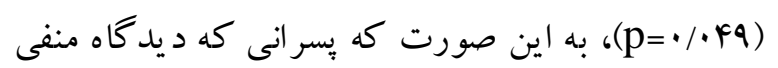
بيشترى نسبت به روابط عاطفى داشتند كه به طور معنى دارى بيشتر از دختران بودند.
نتايج نشان داد كه در مجموع 9V درصد (q (q درصد بسران و Y Y درصد دختران) گروه نمونه تجربه روابط عاطفى را كزارش كردند سايرين كه سب درصد (نزديك

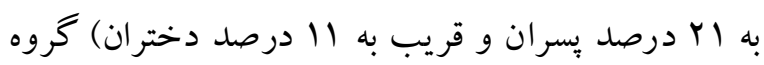
نمونه را شامل مى شدند بيان كرده بودند كه روابط عاطفى لنى نداشتهاند. نتايج آزمون خى دوى دو متغيره نشان داد كه ارتباط معنىدارى بين اين دو متغير وجود ندارد (p=//190) . ضريب همبستخى فى كرامر نيز ارتباط سM//• بين دو متغير رانشان داد. همجنين در مورد تجربه مشكلات بعد از Tان نيز VY درصد از دانشجويان (II)

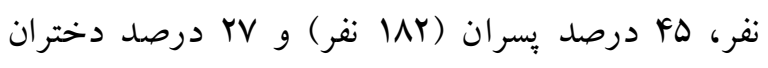
(9.9 (1) ) اظهار داشتند كه مشكلاتى را تجربه كردهاند

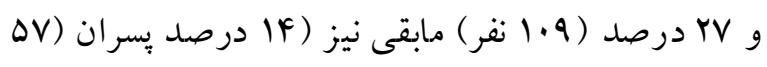
نفر) و سا درصد دختران (Ur نفر)) اعلام كردهاند كه لند 
كلمو ₹روف اسميرنوف ه1/1/ با سطح معنادارى

•

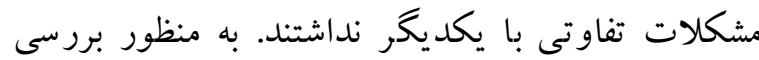
رابطه بين سن و تجربه يا عدم تجربه مشكلات و همجنين يذيرش يا عدم يذ يرش رابطه عاطفى و همين طور شكست

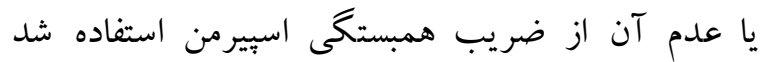

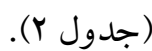

همجنين نتايج نشان داد كه بين مقطع تحصيلى با ديدگاه نسبت به روابط عاطفى (199F) • ميزان مشكلات متعاقب روابط عاطفى ( مقطع تحصيلى با تجربه شكست بين دو كروه تفاوت معنادارى وجود ندارد ( (p=×.9V). به منظور بررسى رابطه بين جنسيت و نوع مشكلات تجربه شده از آزمون كلموگروف اسميرنوف دو بعدى استفاده شد. نتايج آزمون رابطه معنى دارى بين اين دو متغير نشان نداد (اماره

جدول r نتايج آزمون ضريب همبستكى بيرسون براى متغير هاى سن با روابط عاطفى، ديدكاه نسبت به آن و تجارب بعدازآن

\begin{tabular}{|c|c|c|c|}
\hline \multicolumn{3}{|c|}{ سن } & \multirow{2}{*}{ روابط عاطفى } \\
\hline معنادارى & ضريب همبستكى & فراوانى & \\
\hline.$/ . \mu F$ & $-\cdot / 11 r^{*}$ & rof & تجربه شكست \\
\hline .1941 &.$/ . r 4$ & Mr & مشكلات عاطفى \\
\hline.$/ Y 19$ & -.1 .94 & MVF & ديد كاه به روابط عاطفى \\
\hline
\end{tabular}

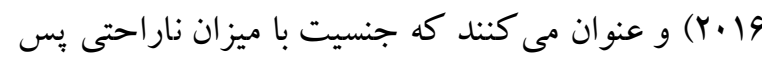
از رابطه ارتباط دارد (فيلد و همكاران، · · (Y) و مجموعه

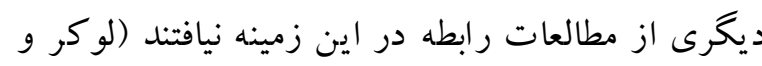

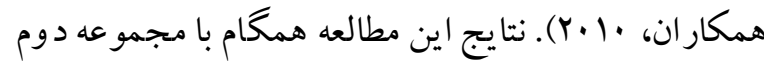
از تحقيقات ارتباط جنسيتى خاصى را نيافت غيرازاينكه يسران بيشتر از دختران ديدكاه منفى نسبت به روابط عاطفى نشان د ادند. در مورد اينكه آيا دختر ان بيشتر از اين فرايند جدايى و شكست در رابطه عاطفى متأثر مىشوند يا پسران به نظر مىرسد كه تبيينهاى ديخرى داشته باشد.

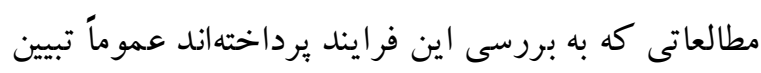

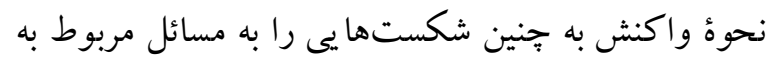
بيوند دلبستكى ربط مىدهند و بيان مى كنند كه بيوند دلبستكى مناسب ييش بينى كننده مناسبى براى واكنش بخته در اين جنين روابطى خواهد بود (مارشال و
همانطور كه در جدول آمده است نتايج نشان داد كه بين سن و مشكلات عاطفى (19 / •

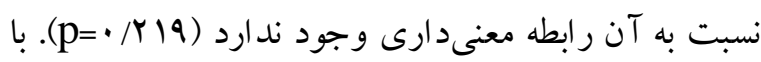
اين وجود تجربه شكست با افزايش سن همبستكى منفى معنادارى (p=/ (p = نشان داد به اين معنا كه با افزايش سن ميزان شكست در روابط عاطفى كاهش مى يابد.

هدف از اين مطالعه بررسى رابطة بين تجربه روابط عاطفى و ارتباط آن با متغيرهاى جمعيت شناختى و ديدگ دراه دانشجويان نسبت به آن بود. در مورد ارتباط بين جنسيت و واكنش به فقدان و متأثر شدن از آن نتايج متفاوتى وجود دارد كه بعضى از محققين يكى از دو جنس را

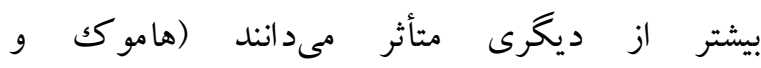

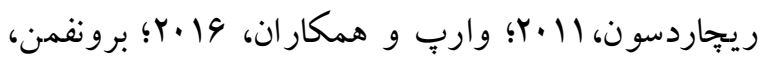


عاطفى مى يردازند و از تجارب مثبت آن غفلت مىورزند.

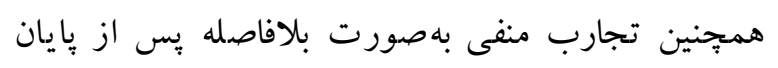

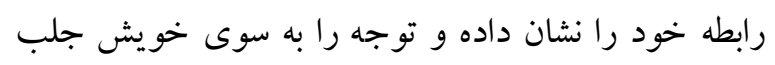

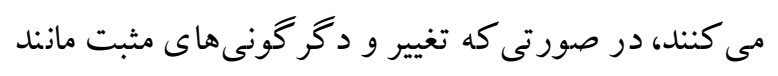

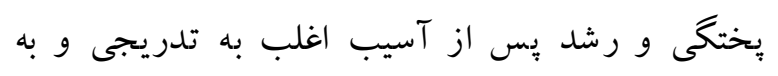

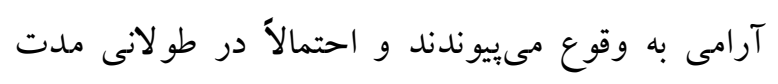
بيشتر وضوح مىيابد. همجنين مىتوان اشاره كرد كه بيشتر تحقيقات كمى به گونهاى طراحى و اجرا شدهاند كه جندان زرفاى اين تجربه را مورد مداقه قرار نمىدهند

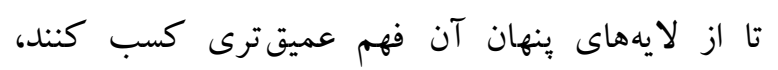
درصورتى كه ماهيت اين تجربه به گونهاى است كه در

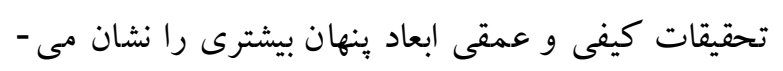

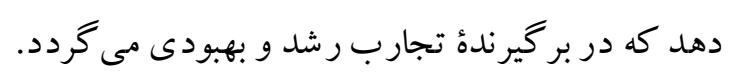

\section{نتيجه تيرى}

نتايج نشان داد كه بيوند عاطفى تجربهاى شايع در ميان دانشجويان است و نزديك به دوسوم دانشجويان آن را نـان

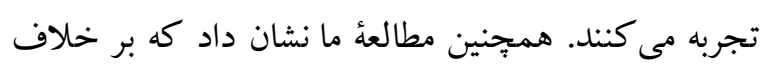
تصور رايج كه عمو ماً از آن به عنوان تجربهاى منفى ياد مى كنند و على رغم اينكه بيشتر آنان متعاقب آن رابطه دجار مشكلاتى از قبيل مشكلات تحصيلى، هيجانى، خانوادگى و ... شدند با اين وجود اغلب دانشجويان

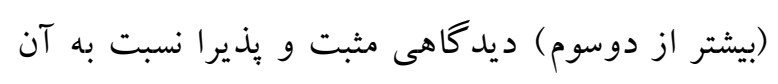
داشته و آن را تجربهاى خوشايند و مفيد عنوان كردند. همجِين جنسيت نقش تعيين كنندهاى در داشتن يا نداشتن رابطه عاطفى و تجربه مشكلات بعد از آن نداشت و برخلاف تصور رايج دختران مشكلات بيشترى را بعد از رابطه تجربه نمى كنند و دو جنس تفاوتى در آن نشان ندادند. علاوه بر اين پِران ديدكاه منفى بيشترى از

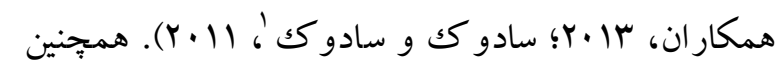
بعضى مطالعات بيوند بين شكست و واكنش در روابط را به مسائل شناختى مانند عزت نفس، انعطاف شناختى و

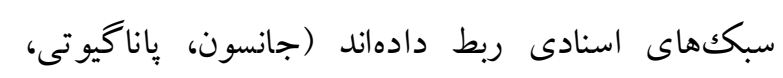
باس، رمزى و هريسون؛ Y. VV)؛ بنابراين تبيين اين تجارب را بيشتر بايد متناسب با اين مقولهها بررسى كرد تا

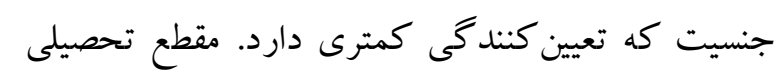
نيز نقش مؤثرى در ر ابطه با مسائل عاطفى و ديدگاه نسبت

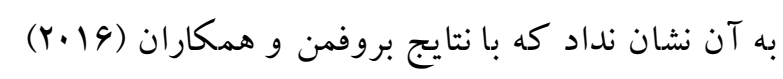

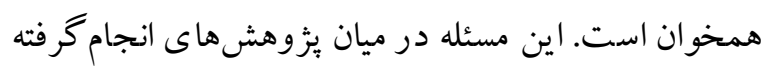

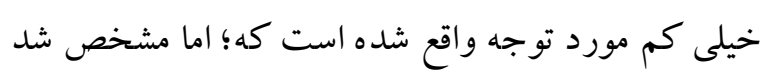
كه به مواز ات افزايش سن تجربيات شكست نيز كاهش مى يابد. اين مورد مى تو اند دلايل احتمالى خاصى داشته باشد. شايد دليل كاهش آن به خاطر اين باشد كه خيلى از افراد در سنى بالاخره به فردى وابسته شده و رابطه با وى را ادامه داده كه اين افزايش احتمال وابستكى با افزايش سن ارتباط دارد و به همين دليل آثار نايختخى هاى اوليه در روابط بين -فردى كاسته و به موازات آن نيز كزارش آن كاهش مى يابد. هرجند اين مطالعه نيز همانند خيلى از مطالعات ديخر جنبه هاى منفى و عوارض ناخوشايند ناشى از تجربيات

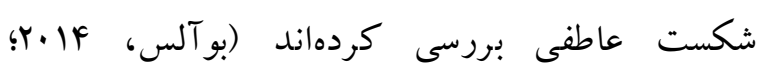

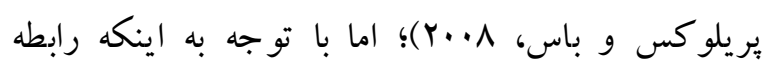

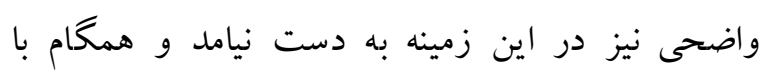
مطالعاتى كه جنبههاى مثبى را براى آن برشمردهاند

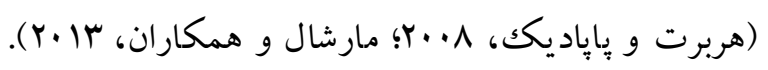
در مجموع بايد خاطر نشان ساخت كه اغلب مطالعات به جنبهاى مرضى و آسيبشناختى يّ از پيايان رابطهُ

1- Sadock \& Sadock
2- Johnson, Panagioti, Bass, Ramsey \& Harrison 
محرمانكى و حفظ حريم شخصى شر كت كنند كان در

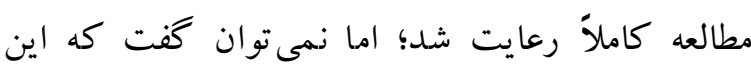
رفتارها نيز تضمين كننده و رافع تمامى موانع باشد، جرا كه هيجانهاى ناخوشايندى همجِون شرم و احساس كناه صحبت كردن در مورد روابط عاطفى خاتمه يافته را تبديل به امر مشكلى مى كند. همجِين استفاده از

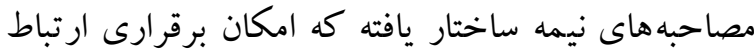
بيشترى را فراهم مى كند هم به عمق اطلاعات مىافزايد هم زمينهاى براى اعتماد بين -فردى بين إزوهش گر ر و

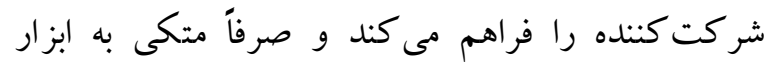
يزّوهش نيست كه مى تواند رد مطالعات آتى مورد بررسى بيشترى قرار بخيرد.

\section{سياسگز ارى}

از كلئ د انشجويان كرامى كه در تكميل اطلاعات مورد نياز براى اين بثزوهش ياريخر ما بودند سباسگز اريم.

\section{References}

Boals A. (2014). Using Event Centrality to Predict Depressive Symptoms after a Romantic Conflict: A Prospective Design. Applied Cognitive Psychology, 28(2), 259-265.

Boelen PA, \& Reijntjes A. (2009). Negative cognitions in emotional problems following romantic relationship break-ups Stress and Health, 25(1), 11-19.

Bronfman G, Ladd-Luthringshauser H, Goodman LR, \& Sockol LE. (2016). Predictors of Breakup Distress Among Residential College Students. College Student Affairs Joumal34(3), 3-12

Cameron A, Palm K, \& Follette V. (2010). Reaction to stressful life events: What predicts symptom severity? Journal of Anxiety Disorders, 24(6), 645-649.
دختر ان نسبت به روابط عاطفى نشان دادند. همبجنين مقطع تحصيلى رابطه معنادارى با هيج يكك از متغيرها نشان نداد؛ اما مشخص شد كه با افزايش سن تجربيات شكست كاهش بيدا مى كند.

به نظر مىر سد كه برداختن به جنبه هاى مثبت اين روابط نيز مفيد باشد. از اين روى، براى مطالعات آتى بيشنهاد مىشود كه جنبه هاى مثبت اين تجارب نيز بيشتر مورد بررسى قرار بحيرند. علاوه بر اين، بررسى بيشتر مسائل عاطفى در ارتباط با سبككهاى دلبستخى و مؤلفههاى شناختى مى تواند دانش مفيدى را براى ما در بر داشته باشد و مى تواند موضوع مناسبى براى تحقيقات آتى باشد. همجينين مطالعه و تبيين روانشناختى اين تجارب بر اساس نظريههاى رشدى و تطبيق آن با مراحل رشدى جوانان در اين سنين، مى تو اند مطالب مفيدى را آشكار سازد. بدين منظور بررسى هايى در قالب مطالعات طولى مىتواند دلالتها و بينشهاى بيشترى در اين زمينه به دست دهد كه خيلى كمتر مورد بررسى قرارگرفته است. درواقع فرهنگ و مسائل فرهنگى يكى از جنبههاى خيلى مهم

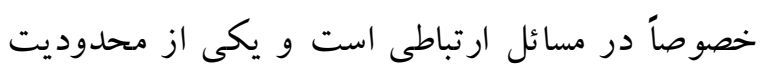

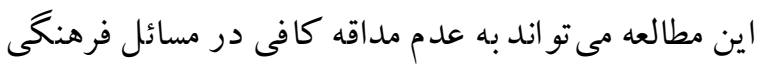

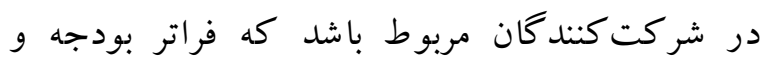
امكانات مالى و زمانى ما بود كه نياز به مطالعه عمقى و بررسى طولانى مدت دارد. همجنين از آنجايى كه تجربه روابط عاطفى در جامعهُ ما تجربهاى است كه حساسيت هاى فرهنكى خاصى در مورد آن وجود دارد. درنتيجه افراد جندان مايل نيستند كه در مورد اين روابط اطلاعاتى را در اختيار ديخران قرار دهند كه يكى از محدوديتهاى ديخر مطالعه ما بود. هر جند كه تلاش بر اين بود كه اين جنبه تا حد امكان خنثى شود و اصول رازدارى و 
Chen Z, Guo F, Yang X, LiX, Duan Q, Zhang J, \& Ge X. (2009). Emotional and Behavioral Effects of Romantic Relationships in Chinese Adolescents. Joumal of Youth and Adolescence, 38(10), 1282-1293.

Chung MC, \& Hunt LJ. (2014). Posttraumatic Stress Symptoms and WellBeing Following Relationship Dissolution: Past Trauma, Alexithymia, Suppression Psychiatric Quarterly, 85(2), 155-176.

Eastwick PW, Finkel EJ, Krishnamurti T, \& Loewenstein G. (2008). Mispredicting distress following romantic breakup: Revealing the time course of the affective forecasting error. Joumal of Experimental Social Psychology, 44(3), 800-807.

Field T, Diego M, Pelaez M, Deeds O, \& Delgado J. (2009). Breakup distress in university students. Adolescence, 44(176), 705-727.

Field T, Diego M, Pelaez M, Deeds O, \& Delgado J. (2010). Breakup distress and loss of intimacy in university students. Psychology, 1(03), 173 177.

Franklin AE. (2015). The role of positive psychological factors and coping strategies following a nonmarital relationship breakup. (Doctor of Psychology - Clinical), The Australian National University.

Gilbert SP, \& Sifers SK. (2011). Bouncing Back froma Breakup: Attachment, Time Perspective, Mental Health, and Romantic Loss. Joumal of College Student Psychotherapy, 25(4), 295310.

Hammock G, \& Richardson DS. (2011). Love Attitudes and Relationship Experience. The Joumal of Social Psychology, 151(5), 608624.

Hawley AR, Mahoney A, Pargament KI, \& Gordon AK. (2015). Sexuality and spirituality as predictors of distress over a romantic breakup: Mediated and moderated pathways. Spirituality in ClinicalPractice, 2(2), 145-159.

Hebert S, \& Popadiuk N. (2008). University students' experiences of nonmarital breakups: A grounded theory. Journal of College Student Development, 49(1), 1-14.
Johnson J, PanagiotiM, Bass J, Ramsey L, \& Harrison R. (2017). Resilience to emotional distress in response to failure, error or mistakes: A systematic review. Clin Psychol Rev, 52, 1942.

Locker JrL, McIntosh WD, Hackney AA, Wilson JH, \& Wiegand KE. (2010). The Breakup of Romantic Relationships:SituationalPredictors of Perception of Recovery. North American Joumal of Psychology, 12(3), 565-578.

Mahmoudi Panah H, Sohrabi F, \& Jafari A. (2019). RelationalBreakup and Anxiety Experience in Kurdistan University Students in 2018. Third International Conference on Innovation and Research in Educational Sciences, Management and Psychology. (In persian)

Marshall TC, Bejanyan K, \& Ferenczi N. (2013). Attachment Styles and Personal Growth following Romantic Breakups: The Mediating Roles of Distress, Rumination, and Tendency to Rebound. PLoSONE, 8(9), 1-11.

Perilloux C, \& Buss DM. (2008). Breaking up romantic relationships: Costs experienced and coping strategies deployed. Evolutionary Psychology, 6(1), 164-181.

Rhoades GK, Kamp Dush CM, Atkins DC, Stanley SM, \& Markman HJ. (2011). Breaking up is hard to do: The impact of unmarried relationship dissolution on mental health and life satisfaction. Journal ofFamily Psychology, 25(3), 366-374.

Sadock BJ, \& Sadock VA. (2011). Kaplan and Sadock's synopsis of psychiatry: Behavioral sciences/clinical psychiatry: Lippincott Williams \& Wilkins.

SohrabiF, Yousefi U, \& Mahmoudi Panah H. (2019). The Prevalence of relationship breakup and its Effects on Students' Functioning in Kurdistan University 2018. Third Intemational Conference on Innovation and Research in Educational Sciences, Management and Psychology. (In persian)

Tardast K, \& Aman Allahy A. (2015). Prediction of general health based on the components of self-compassion among Ahwaz universities 
girls with love breakup experience. Family Research, 43(11), 385-407. (In persian)

Waller KL, \& Mac Donald TK. (2010). Trait SelfEsteemModerates the Effect of Initiator Status on Emotional and Cognitive Responses to Romantic Relationship Dissolution. Journal of Personality, 78(4), 1271-1299.

Wrape ER, Jenkins SR, Callahan JL \& Nowlin RB. (2016). Emotional and Cognitive Coping in Relationship Dissolution. Journal of College Counseling, 19(2), 110-123.

Yousefi U, Jafari A, MahmoudiPanahH, \& SohrabiF. (2019). Experience of relationship breakup and its relation to depression in students of Kurdistan University in 2018. Third International Conference on Innovation and Research in Educational Sciences, Management and Psychology. (In persian). 